\title{
Sarcoid-like paracoccidioidomycosis: case report
}

\author{
Paracoccidioidomicose sarcoídica: relato de caso
}

Carlos Arthur de Figueiredo Athayde ${ }^{1}$, Caroline Cruz Barbosa Nacif ${ }^{1}$, Omar Lupi ${ }^{2}$, Ricardo Barbosa Lima ${ }^{1}$, Marcelo Rosandiski Lyra ${ }^{3}$, Antônio Macedo $D^{\prime}$ Acri $^{3}$, Carlos José Martins ${ }^{1}$

\begin{abstract}
Paracoccidioidomycosis (PCM), which is caused by the dimorphic fungus Paracoccidioides spp, is the most prevalent systemic mycosis in immunocompetent individuals in Brazil. The fungus lives in the soil and usually infects the patient through inhalation of airborne propagules, the lungs being the portal of entry. In areas of larger endemicity, such as Brazil, the annual incidence reaches 3 cases per 100,000 inhabitants. Cutaneous lesions in PCM are frequent and ulcer or ulcerous-vegetative lesions are the commonest morphological type, followed by the infiltrative pattern. The histology shows a dermal granulomatous inflammation. Infiltrative PCM can be easily misdiagnosed, once clinical and histological similarities may occur specially with cutaneous sarcoidosis. We describe a case of cutaneous paracoccidioidomycosis misdiagnosed as sarcoidosis both in clinical examination and in the histopathological analysis. Further exams confirmed Paracoccidioides sp. as the causative agent through mycological cultures and Grocott's stain. We believe this case may help physicians around the world to suspect and consider PCM as a differential diagnosis, especially if the patient has traveled to endemic area or the current therapy for sarcoidosis lacks clinical improvement.
\end{abstract}

Keywords: Paracoccidioidomycosis. Sarcoidosis. Mycoses. Diagnosis, Differential.

\begin{abstract}
RESUMO:
Importância do problema: Paracoccidioidomicose ( $P C M)$ é a micose sistêmica mais prevalente em indivíduos imunocompetentes no Brasil, sendo causado pelo fungo dimórfico Paracoccidioides spp. 0 fungo vive no solo e geralmente sua porta de entrada no paciente ocorre pelos pulmões por inalação de propágulos presentes no ar. Em áreas de maior endemicidade, como no Brasil, a incidência chega a três casos por 100 mil habitantes. As lesões cutâneas na PCM são frequentes. Lesões ulceradas ou ulcerovegetantes são os tipos morfológicos mais comuns, sendo o padrão infiltrativo o segundo mais descrito. A histologia demonstra inflamação granulomatosa na derme. A PCM infiltrativa pode ser facilmente confundida com sarcoidose, visto que ambas possuem similaridades clínicas e histopatológicas. Comentários: Nós descrevemos um caso de PCM cutânea com diagnóstico inicial incorreto de sarcoidose, tanto pelo quadro morfológico, como pelo exame histopatológico semelhante. Exames posteriores revelaram a presença de Paracoccidioides sp na coloração pelo Grocott e na cultura do material para fungos. Os autores acreditam que esse caso possa ajudar médicos a suspeitarem e considerarem PCM no diagnóstico diferencial de lesões cutâneas infiltrativas, especialmente se houver história epidemiológica de viagem a área endêmica ou resposta insatisfatória ao tratamento para sarcoidose.
\end{abstract}

Palavras-chave: Paracoccidioidomicose. Sarcoidose. Micoses. Diagnóstico Diferencial.

1. MD, (Hospital Universitário Gaffree e Guinle - Universidade Federal do Estado do Rio de Janeiro - UNIRIO)

2. MD, PhD (Hospital Universitário Gaffree e Guinle - Universidade Federal do Estado do Rio de Janeiro - UNIRIO)

3. MD, PhD (Fundação Oswaldo Cruz - Fiocruz)
CORRESPONDÊNCIA: Carlos Arthur de Figueiredo Athayde Hospital Universitário Gaffree e Guinle - Universidade Federal do Estado do Rio de Janeiro - UNIRIO 


\section{Introduction}

Paracoccidioidomycosis (PCM) is the most prevalent systemic mycosis in immunocompetent individuals in Brazil and is caused by the dimorphic fungus Paracoccidioides spp. ${ }^{1,2,3}$ In the past, PCM was thought to be caused by $P$. brasiliensis, but a new species, $P$. lutzii, was discovered in the central-western region of Brazil. ${ }^{3} P$. lutzii is composed of a single monophyletic and recombining population so far found in central, southwest, and north Brazil and Ecuador. On the other hand, P. brasiliensis contains a complex of at least four different cryptic species (S1, PS2, PS3 and PS4). ${ }^{4}$

The fungus lives in the soil and usually infects the patient through inhalation of airborne propagules, the lungs being the portal of entry. ${ }^{1,5}$ In areas of larger endemicity, such as Brazil, the annual incidence reaches 3 cases per every 100,000 inhabitants. ${ }^{6}$

Cutaneous lesions in PCM are frequent and ulcer or ulcerous-vegetative lesions are the commonest morphological type followed by the infiltrative pattern. The histology shows a dermal granulomatous inflammation. Infiltrative PCM can be easily misdiagnosed, since clinical and histological similarities may occur specially with cutaneous sarcoidosis $^{1}$ as we show in our patient.

\section{Case Report}

A 24 year-old male student, resident in a rural county in Rio de Janeiro, Brazil, presented a 2-year history of erythematous infiltrated lesions on the face and chest. He had a histopathological exam that indicated sarcoidosis and received treatment with intralesional injection of corticosteroid and cryosurgery with no clinical response. The patient had no history of smoking or alcohol abuse.

Dermatologic examination revealed well-limited, erythematous infiltrated plaques on the left ear lobe (Fig.1a), cervical area (Fig.1b), right axilla (Fig. 2a-b) as well as two similar lesions on the right side of the chest. No mucous membrane lesions or systemic symptoms were observed.

A new histopathological examination showed a dermal granulomatous inflammatory infiltrate. (Fig. 3a) Grocott's stain identified yeast-like structures with multiple budding and double membrane, characteristic of Paracoccidioides spp. (Fig. 3b). There was growth of white, cottony colonies on Sabouraud-agar medium, with the typical aspect of "popped popcorn" at $25^{\circ} \mathrm{C}$. (Fig. 3c). Cultures on Sabouraud-agar successfully switched its morphology to yeast-form growth at $37^{\circ} \mathrm{C}$.

Blood tests and imaging exams (chest $x$-ray, abdominal ultrasonography, chest and abdominal

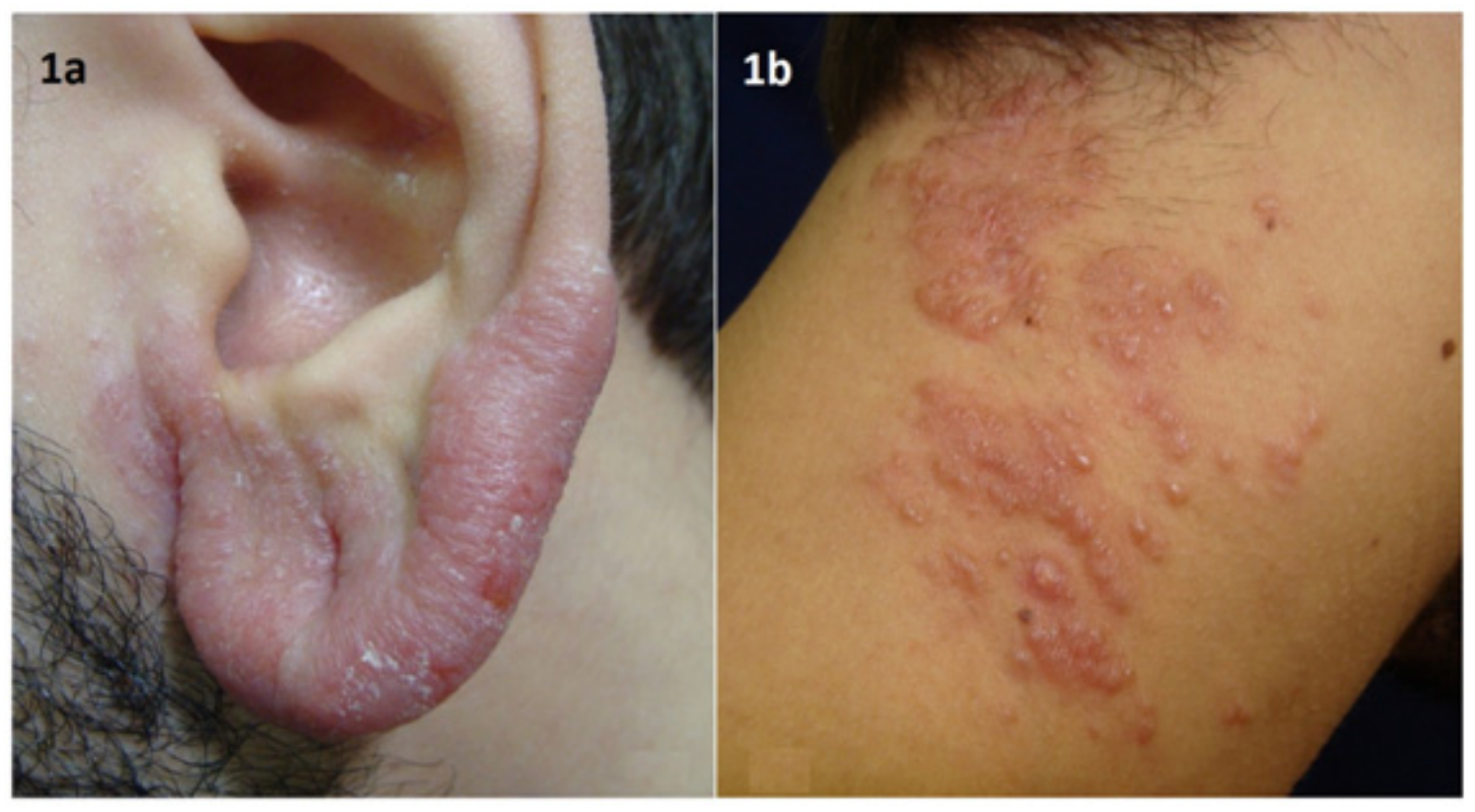

Figure 1: (a) Erythematous infiltrated plaque on the left ear lobe. (b) Papules and plaques on the cervical area. 


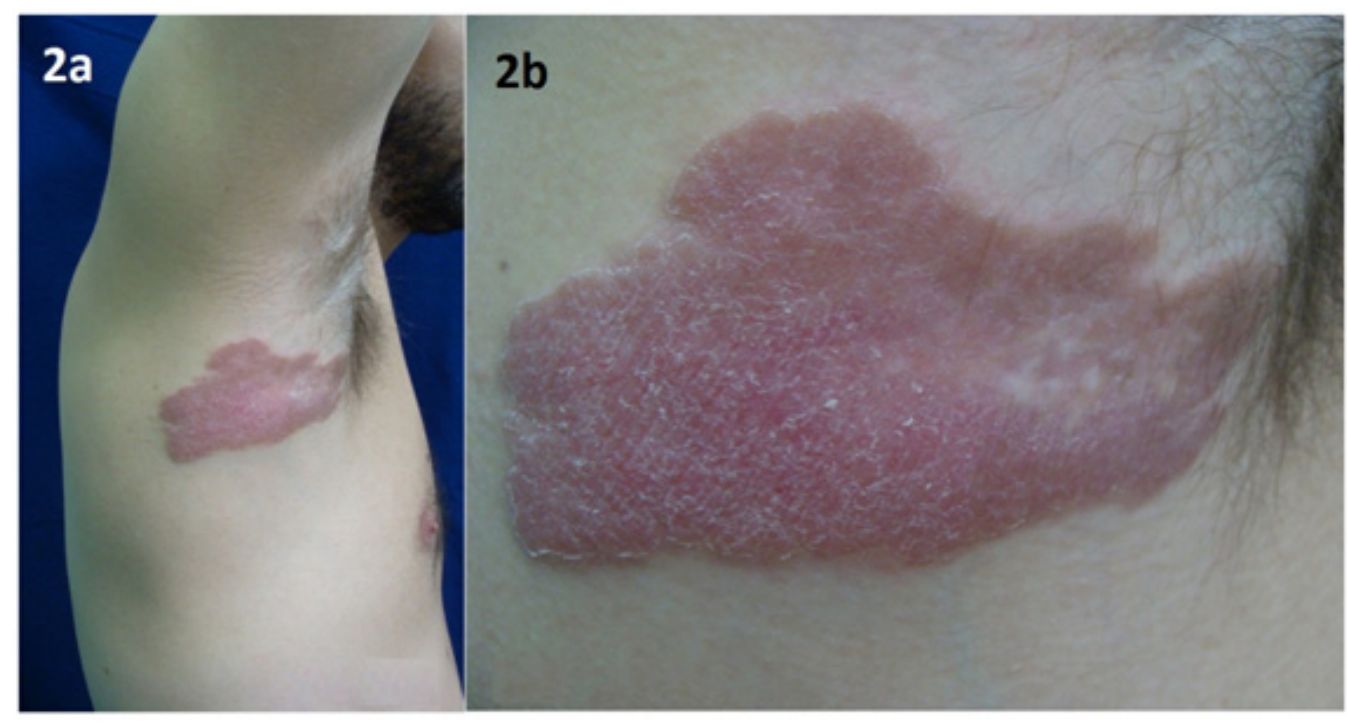

Figure 2: (a) Large, well defined, erythematous infiltrated plaque on the right axilla. (b) Close view of the axilla plaque showing a scaly surface.

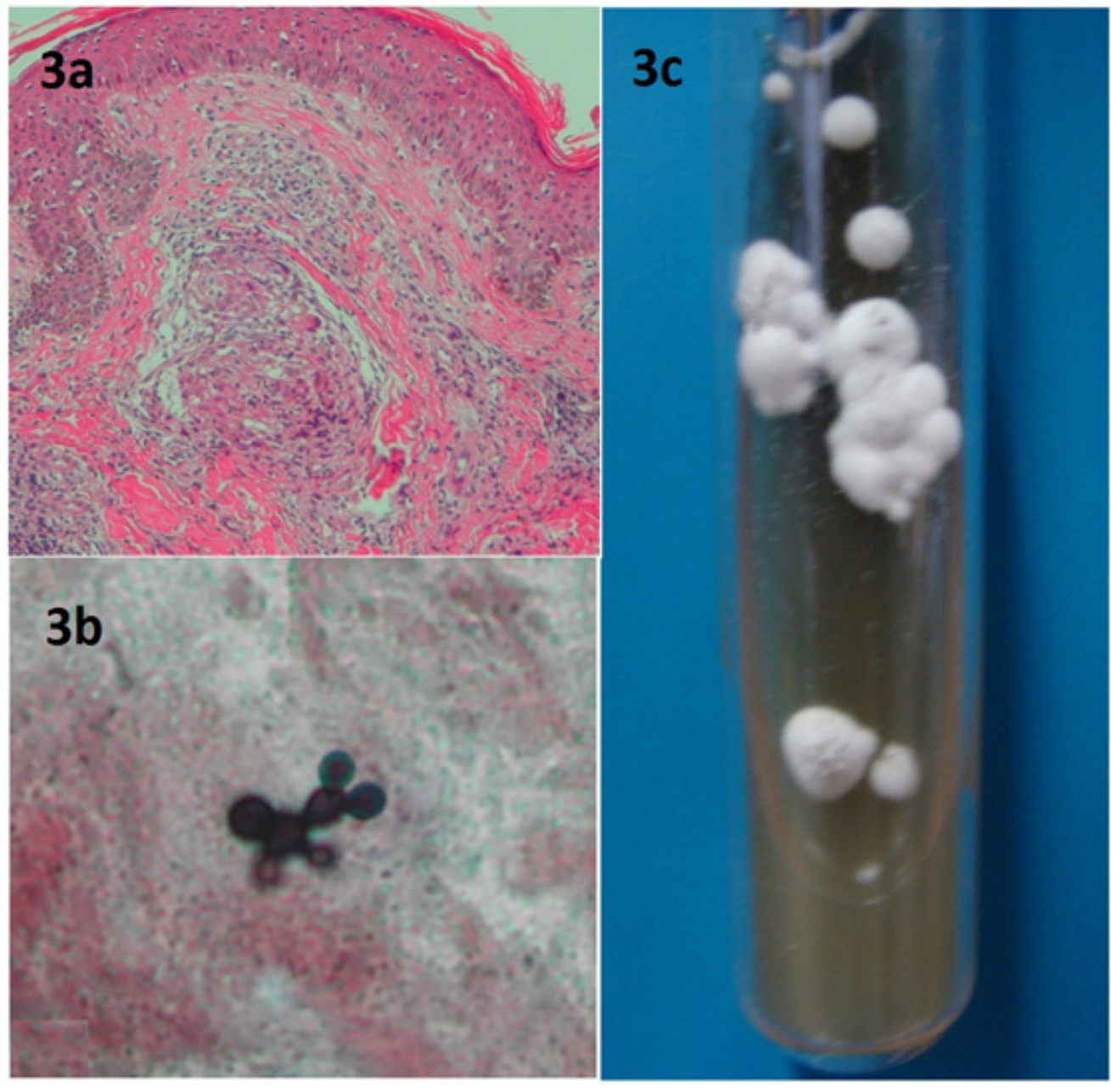

Figure 3: (a) Histology showing dermal granulomatous inflammation (H\&E 100x). (b) Grocott's methenamine silver stain showing yeast-like structures with typical multiple budding and "mickey mouse ears" pattern. $(400 x)$ (c) White, cottony colonies on Saboureaud-agar medium, with the peculiar aspect of "popped popcorn". 
computerized tomography) failed to reveal any systemic involvement. HIV and Mantoux tests results were negative. Cortisol levels after ACTH test did not indicate adrenal insufficiency.

According to those findings, we concluded the diagnosis of PCM, displaying an unusual clinical aspect, similar to sarcoidosis. Therapy with sulfamethoxazole-trimethoprim 1600/320 mg/day orally was started with an estimated treatment time of 24 months. Clinical improvement was observed 30 days later.

\section{Discussion}

The previous diagnosis of sarcoidosis in our patient was based on infiltrated plaques and histological finding of a dermal granulomatous inflammatory infiltrate without identification of fungi or other microorganisms. Clinical and histopathological misdiagnosis may occur due to similarities among cutaneous sarcoidosis, infiltrative PCM and the tuberculoid leprosy. ${ }^{1}$

A similar diagnostic mistake regarding pulmonary lesions was described recently in literature. Coelho et al. (2015) reported 8 cases of pulmonary and disseminated PCM with prior histopathological diagnosis of sarcoidosis (noncaseating granulomas in lung biopsies). ${ }^{3}$ Regarding histopathology, noncaseating granulomas of epithelioid cells with pale-staining nuclei and a rim of few number of lymphoid cells surrounding the granuloma, the naked tubercle, is suggestive of sarcoidosis. ${ }^{1}$ In PCM, hematoxylin and eosin (H\&E) stained sections usually show a mixed suppurative and granulomatous inflammatory infiltrate composed primarily of neutrophils admixed with epithelioid histiocytes. Nevertheless, a noncaseating epithelioid granuloma, similar to those found in sarcoidosis, can be observed. Yeast-like cells can be difficult to visualize with routine staining (H\&E), and a special stain should be used for screening tissue for the presence of fungal elements. ${ }^{3}$

In a country where leprosy is still a public health problem and the primary care physician is instructed to be alert to that disease, misdiagnosis between infiltrative PCM and tuberculoid leprosy could be understood as acceptable at the first moment. ${ }^{1}$ Marques et al (2008) reported a case of PCM misdiagnosed as tuberculoid leprosy, that he called sarcoid-type PCM. He emphasized that histological diagnosis of granulomatous infectious diseases will be accurate when there are characteristic microscopic features or sufficient number of infectious agents to be detected by histochemistry analysis. Therefore, the presence of compact epithelioid granulomas, with a central caseous necrosis and dense peripheral lymphocytic accumulation indicates tuberculosis. Granuloma with nerve involvement suggests tuberculoid leprosy, but in lepromatous leprosy the finding will be of a diffuse infiltration with numerous bacilli. ${ }^{1}$

In the present case, the lack of improvement during therapy for cutaneous sarcoidosis and the epidemiologic history from endemic region led us to suspect of PCM and the careful search for the fungus confirmed the diagnosis. The apparent absence of systemic involvement, despite all imaging exams and blood tests, could made us to consider direct cutaneous infection, although respiratory tract is the most frequent portal of entry for this infection. Arguments against this hypothesis are the presence of cutaneous lesions at distant sites with no history of previous trauma that could inoculate the pathogen. Few cases of primary accidental or traumatic cutaneous location of the infection have previously been described. ${ }^{7}$ Most primary cutaneous lesions had small scratches or cuts before the infection. ${ }^{7}$

Reviews of cutaneous manifestations in paracoccidioidomycosis have shown that the infiltrative pattern corresponded to up to $26.6 \%$ of the skin lesions observed, which included the sarcoidosis-like lesions. ${ }^{8}$ According to Marques et al, patients of any age presenting PCM with sarcoidosis-like clinical pattern have few and indolent lesions, as occurred in the patient described in this report, probably as consequence of certain equilibrium between the agent and the host defense. ${ }^{1}$

Several cases of PCM have been described in recent years in Europe associated with populations from endemic regions and travelers. ${ }^{9}$ Martinez (2015) reviewed at least 60 cases of PCM reported and diagnosed in non-endemic countries. Some of them had left the endemic area already presenting clinical manifestations of the mycosis, but most of them had shown lesions after five years of permanence in Latin America. ${ }^{10}$ As we can see, it is essential that physicians consider PCM as differential diagnosis in individuals coming from endemic areas. ${ }^{9}$ 
In conclusion, we present an unusual case of sarcoid-like PCM, where the first clinical and histopathological exams led to an incorrect diagnosis. The lack of clinical healing with the current therapy or the ulceration of a previous infiltrative skin lesion should be understood as a warning signal to review the initial diagnosis. Given the extent of clinical and histopathological overlap between granulomatous infectious and non-infectious diseases, diagnosis of these entities can be challenging and special stains for fungi or mycobacterial pathogens should always be performed. Also, in some rare cases of PCM with localized cutaneous lesion, without other internal foci, it is important to consider the hypothesis of the skin as the primary inoculation site.

\section{References}

1. Marques SA, Lastória JC, Putinatti MSMA, Camargo RMP, Marques MEA. Paracoccidioidomycosis: infiltrated, sarcoidlike cutaneous lesions misinterpreted as tuberculoid leprosy. Rev Inst Med Trop S. Paulo. 2008;50:47-50.

2. Nakamura R, Valgas N, Bichara RM, Brazuna D, Leverone A. Paracoccidioidomycosis: chronic adult unifocal form. Int J Dermatol. 2012;51:195-6

3. Coelho MG, Severo CB, de Mattos Oliveira F, Hochhegger $B$, Severo LC. Paracoccidioidomycosis mimicking sarcoidosis: a review of 8 cases. Mycopathologia. 2016;181:13743.

4. Teixeira MM, Theodoro RC, Nino-Vega G, Begagli E, Felipe MSS. Paracoccidioides species complex: ecology, phylogeny, sexual reproduction, and virulence. PLoS Pathog. 2014; 10: e1004397.

5. Pereira RM, Bucaretchi F, Barison EM, Hessel G, Tresoldi AT. Paracoccidioidomycosis in children: clinical presentation, follow-up and outcome. Rev Inst Med Trop S. Paulo. 2004;46:127-31

6. Ramos-e-Silva M, Saraiva LES. Paracoccidioidomycosis. Dermatol Clin. 2008;26:257-69.

7. García Bustínduy $\mathrm{M}^{1}$, Guimerá $\mathrm{FJ}$, Arévalo $\mathrm{P}$, Castro C, Sáez M, Dorta Alom S, et al. Cutaneous primary paracoccidioidomycosis. J Eur Acad Dermatol Venereol. 2000;14:113-7.

8. Marques, SA. Cutaneous lesions. In: Franco M, Lacaz CS, Restrepo-Moreno A, Del Negro G., ed. Paracoccidioidomycosis. Boca Raton, CRC Press, 1994. p: 259-66.

9. Buitrago MJ, Bernal-Martínez L, Castelli MV, RodríguezTudela JL, Cuenca-Estrella M. Histoplasmosis and paracoccidioidomycosis in a non-endemic area: a review of cases and diagnosis. J Travel Med. 2011;18:26-33.

10. Martinez R. Epidemiology of paracoccidioidomycosis. Rev Inst Med Trop S. Paulo. 2015;57(Suppl. 19):11-20. 